\title{
Celestine from Valea Sarii (Vrancea region): New Data and Crystal Structure Refinement
}

\author{
GHEORGHE BRANOIU*, AURA CEHLAROV, DIANA CURSARU, SONIA MIHAI
}

Petroleum-Gas University of Ploiesti, 39 Bucharest Blvd., 100680, Ploiesti, Romania

\begin{abstract}
In the paper has been analyzed the crystal structure of a celestine sample from Valea Sarii (Vrancea region, Romania) located in the Eastern Carpathians Foredeep. The celestine sample was also studied by optical microscopy, chemical and thermal analysis. The unit cell parameters of the celestine structure refined in the space group Pnma were: $a=8.39769 \AA, b=5.38415 \AA, c=6.88167 \AA$, $Z=4$. The chemical composition of the celestine crystals was determined by EDX analysis. The optical characteristics of the sample were studied by optical microscopy. A new set of the unit cell parameters and fractional coordinates of the celestine crystal structure were determined. Also were determined the bond lengths in the $\mathrm{Sr}-\mathrm{O} 12$ and $\mathrm{SO}_{4}$ polyhedra. The sample was collected in the massive mineralization area of the Valea Sarii ore deposit, the largest celestine ore deposit in Romania.
\end{abstract}

Keywords: celestine crystal structure, EDX, XRD, Rietveld method, Valea Sarii, Romania

\section{Introduction}

In the Earth's crust there are two important natural sources for strontium salts: celestine $\left(\mathrm{SrSO}_{4}\right)$ and strontianite $\left(\mathrm{SrCO}_{3}\right)$. Celestine ore deposits are more widespread than the strontianite ones, and have become the main raw source for the production of strontium salts with great economic value. One of the main uses of strontium carbonate is for the manufacturing of glass cathode ray tubes for TV receivers and computer monitors because it prevents X-ray emission. Other industrial uses of the strontium/strontium carbonate it is referring at the manufacture of special glasses, chemical industry (refining beetroot sugar), pyrotechnics (red firework), paints (glow-in-the-dark paint), ceramics (an ingredient in glazes), dryers, medicine (to treat arthrosis and cerebral sclerosis), stomatology (an ingredient in toothpaste for sensitive teeth), ferrite magnets, zinc refining processes, high-energy betaemitter (as radioactive isotope), for production of metallic strontium and other strontium salts [1-3].

The celestine ore deposit from Valea Sarii (Vrancea) discovered in 1972 is the largest celestine accumulation known so far in Romania with resources estimated at approx. 3.15 million tons of rock with celestine content. The average celestine content determined in the samples collected in the outcrops and in the research drilling executed in the area was $576.84 \mathrm{~g}$ per tons. From the geologicregional point of view, Valea Sarii perimeter (Figure 1) in which was discovered celestine accumulation is located on the external side of the Subcarpathian Unit at the contact with Carpathian Foredeep along of Casin-Bisoca major fault (Pleistocene - Wallachian tectogenesis). Celestine mineralization studied in the paper is deposited in the Miocene Salt Breccia Formation, and in sulphatic diamictite (breccia with gypsum blocks) respectively. Moreover, a "celestine impregnation" was identified in the gypsum blocks, in secondary carbonatites blocks and in the breccia matrix in all outcrops located in the Valea Sarii-Andreiasu alignment (Vrancea region). Mineralogical analyses of the heavy minerals concentrate, separated from the samples collected from both the gypsum blocks and the breccia matrix in the Valea Sarii ore deposit, were evidenced by an association of authigene minerals which includes celestine, sulfides, fluorite, and clear sphalerite [4].

\footnotetext{
*email: gbranoiu@yahoo.com
} 


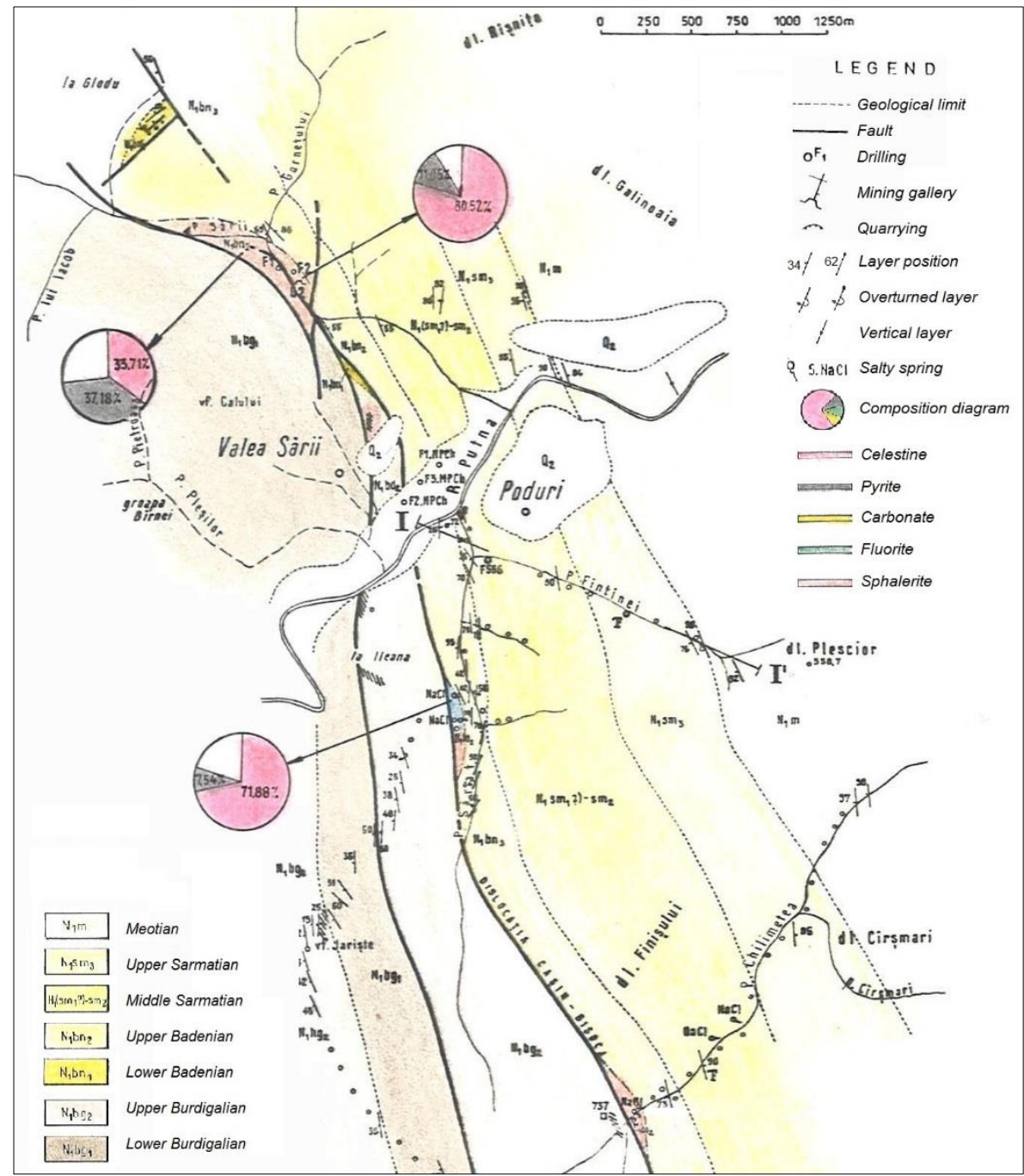

Figure 1. Geological map of the Valea Sarii area (Vrancea region) [4]

The researches performed by Cehlarov [4] on the celestine accumulation in the Valea Sarii River have evidenced three petrographic and genetic distinct types of mineralizations as follows: (1) "mineralization of impregnation" represented by crystals of authigene-primary celestine, this type of mineralization are wide-spread and is typically associated with gypsum and anhydrite; (2) "massive mineralization with replacement character" (metasomatic-diagenetic type); (3) "secondary epigenetic mineralization" as fissure and cavity fillings in the compact mineralization and in surrounding rocks, represented by fibroradial celestine and colomorphous pyrite.

Celestine is fairly widespread and it occurs both as a primary mineral of diagenetic sedimentary environments (associated with carbonate and evaporite rocks), and as a secondary mineral in fissure and cavity fillings in carbonate rocks, in hydrothermal veins and mafic volcanic rocks. The mineral is transparent to translucent, colorless, but also white, pale blue, pale green, brown and black; and with a vitreous luster. Celestine usually forms thin to thick tabular on (001) or (100), sometimes thin prismatic crystals (lath-like) or elongated along (010) or (001) up to several centimeters in size, fibrous, lamellar, massive granular. The cleavage is perfect on (001) and Mohs hardness is $3 \frac{112}{2}$. [2]

The mineral sample used in the study belongs to the collection of the Mineralogy Laboratory of the Petroleum-Gas University of Ploiesti. Celestine crystals are transparent, bluish-gray-brown, vitreous luster, tabular habit, sometimes prismatic habit, and forming lath-like aggregates of small to medium size (1 to $5 \mathrm{~mm}$ ) represented by lamellar crystals dominated by two large basal pinacoid faces (001) truncated by small prism faces (011), (101) and (210) forming a jutting angle on every side and 
sometimes pinacoid faces (010). Macroscopically the sample studied appears as compact, crystalline mineralization, with saccharide texture.

In the paper we carried out a chemical-mineralogical investigation using optical microscopy, EDX spectrometry, X-rays diffraction, and thermal analyses, on a celestine crystal stone from Valea Sarii ore deposit located in the Vrancea region (Eastern Romania).

\section{Materials and methods}

The crystals used in the study originate in the celestine ore deposit from Valea Sarii (Vrancea district - Romania) and were provided by Ph.D. geologist Aura Cehlarov who spent a good part of her professional activity studying this ore deposit.

In order to study the celestine optical characteristics were manufactured thin sections and were performed mineralogy-petrographic observations at optical polarizing microscope Leica type in the Mineralogy Laboratory.

Chemical elemental analysis of the samples was performed by SEM-EDX using a Hitachi S3400-N microscope equipped with an Oxford Instruments X-act energy dispersive X-ray (EDX) spectrometer, operated using the Inca software package. The generated spectra were determined and analyzed by an EDX spectrometer, with $125 \mathrm{eV}$ resolutions, and detector active area $10 \mathrm{~mm}^{2}$.

Thermal analysis consisting of thermogravimetric (TG) and differential thermogravimetric (dTG) curves were recorded on the thermogravimetric analyzer (Setaram LABSYS Evo) by using a $400 \mu l$ alumina crucible. The thermal analysis was conducted at a heating rate of $10^{\circ} \mathrm{C} / \mathrm{min}$ from $30{ }^{\circ} \mathrm{C}$ to $1000^{\circ} \mathrm{C}$ in $\mathrm{Ar}$ atmosphere at $200 \mathrm{~mL} / \mathrm{min}$. A sample size of approximately $125 \mathrm{mg}$ was used.

$\mathrm{X}$-ray diffraction (powders method) was performed using a Bruker D8 Advance diffractometer having following measurement parameters: Bragg-Brentano geometry, $\theta-\theta$ type, CuK $\alpha$ radiation $(\lambda=$

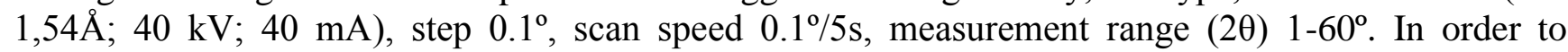
perform the XRD measurement the celestine sample was fine grinded manually in an agate mortar. The interpretation of the XRD measurements was performed both qualitative and quantitative. The qualitative interpretation was carried out using Diffracplus Basic software with Search/Match option and PDF-ICDD 2-2008 database. The phase identification was made using "best quality marks" (*=high quality), after removing the background and $\mathrm{K} \alpha 2$ radiation. The quantitative interpretation was performed using Diffracplus Topas 4.1 software by Rietveld method.

\section{Results and discussions}

Celestine (also known as celestite) has an orthorhombic symmetry in the space group Pnma and belongs to the barite isostructural group. The crystal structure is composed of $\left(\mathrm{SO}_{4}\right)$ tetrahedral groups which lie on mirror planes $m$ type, have two oxygens of the $\left(\mathrm{SO}_{4}\right)$ group in the same mirror plane $(010)$ with sulfur atoms, and the other two oxygens are symmetrical to the plane. Also, the atoms of strontium lie on the mirror planes with the sulfur and two of oxygen atoms. Each strontium atom is twelve-coordinated by oxygen atoms as each oxygen atom is four-fold coordinated by three strontium atoms and to one sulfur atom. Strontium-oxygen (Sr-O) bond lengths are in the range 2.51-3.25 $\AA$, and sulfur-oxygen (S-O) bond lengths are in the range 1.45-1.48 $\AA$. In terms of the geometry of the $\left(\mathrm{SO}_{4}\right)$ and (Sr-O12) polyhedra the celestine structure is most distorted than the barite structure [5-11].

X-ray diffraction studies (sometimes supplemented by other investigation methods) of the celestine structure and other isostructural sulfates were prepared by a series of authors starting in the last century. The crystal structure of celestine was initially solved by James and Wood [12] in space group Pbnm with a trial-error method, and they also showed that celestine, barite and anglesite are isostructural. Further, the crystal structure of celestine has been refined also in the space group Pbnm by Jacobsen et al. [7], Antao [8], Garske and Peacor [10], Miyake et al. [13], Sitepu and Zaidi [14]. The celestine crystal structure was also refined in the space group Pnma by Hawthorne and Ferguson [9] and Brigatti et al. [11]. 
In order to determine structural trends that are expected across the isostructural series of barite, celestite and anglesite, Antao [8] performed refinements of the structures of the three isostructural minerals (celestine, barite and anglesite) showing interesting data on the geometry of the $\left(\mathrm{SO}_{4}\right)$ groups. Brigatti et al. [11] provided an interesting study of the structure refinement of Ba-rich celestine of volcanic origin. Sitepu and Zaidi [14] reported structure refinements on various mixtures of barite and celestine powders, the results agreed reasonably well with the single-crystal XRD data.

\subsection{Chemical composition}

In order to determine the chemical composition, several celestine crystals were selected for EDX analysis. Quantitative analysis carried out with the SEM-EDX system revealed the following elemental content: Sr, Ba, S, O. Standard deviation of EDX analysis shows normal values for this type of investigations in the range 0.6-1.1. The average chemical elemental composition (wt.\%) is presented in Table 1.

Table 1. Average chemical elemental composition of the celestine

\begin{tabular}{|c|c|c|}
\hline Chemical element & wt.\% & Standard deviation $(\sigma)$ \\
\hline $\mathrm{Sr}$ & 45.70 & 1.00 \\
\hline $\mathrm{O}$ & 34.80 & 1.10 \\
\hline$S$ & 17.10 & 0.60 \\
\hline $\mathrm{Ba}$ & 2.40 & 0.70 \\
\hline TOTAL & 100.00 & \\
\hline
\end{tabular}

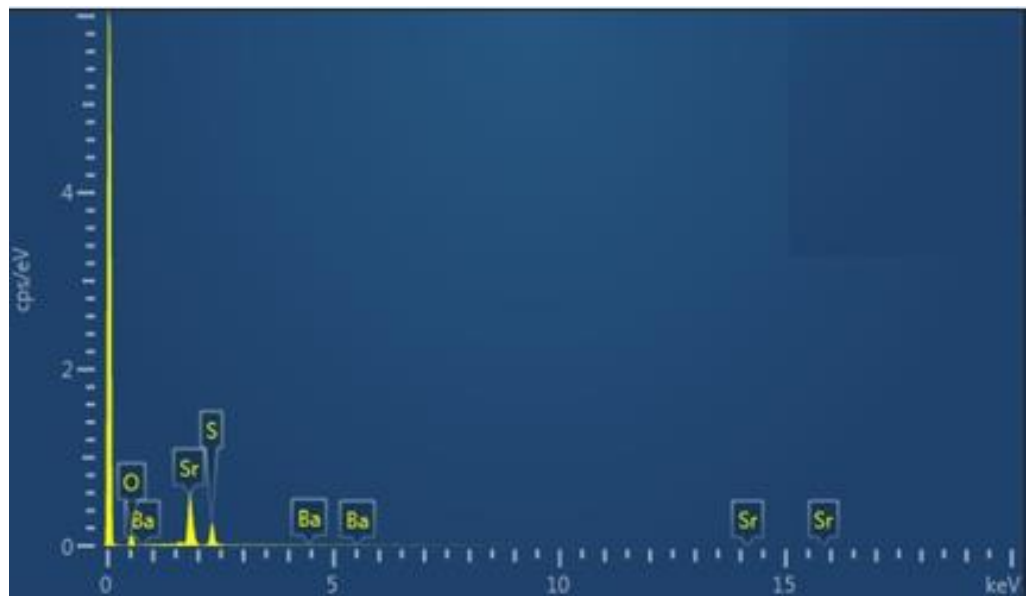

Figure 2. EDX analysis of the celestine

\subsection{Optical microscopy}

The thin sections investigation in the optical polarizing microscope revealed an association of transparent and large crystals of celestine with massive texture. The contour of the crystals is rhombic, idiomorphous, sometimes pseudo-rhombic, corresponding to prismatic habit. The crystals show distinct crystallographic contours and no inclusions. The size of the crystals is in the range of 0.0930$1.250 \mathrm{~mm}$. The refractive indices of the celestine sample are $n_{g}=1.629$ and $n_{p}=1.621$. The sample show gray-yellow birefringence colors of $1^{\text {st }}$ order and weak pleochroism in blue tones and right extinction. 


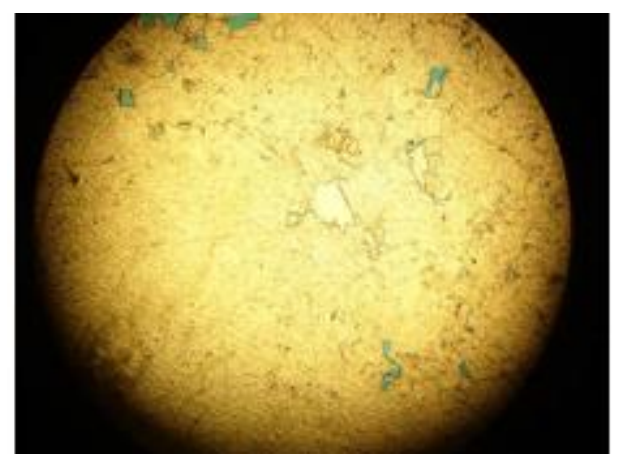

Figure 3. Association of transparent crystals of celestine with rhombic contour and massive texture (N II, 40X)

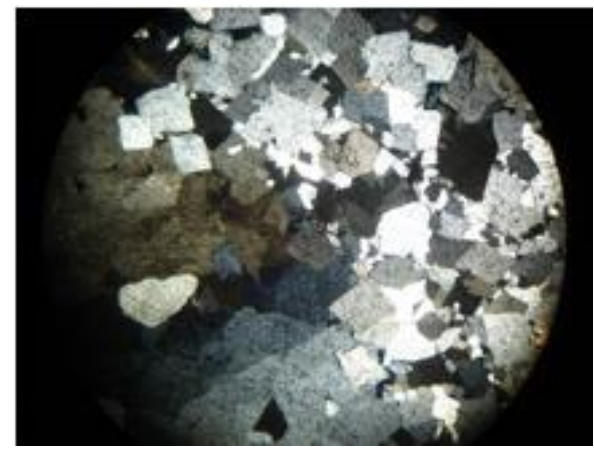

Figure 4. Association of transparent crystals of celestine with rhombic contour and massive texture $(\mathrm{N}+, 40 \mathrm{X})$

\subsection{Thermal analyses}

Thermal curves (thermogravimetric and thermogravimetric differential) shows a typical behavior of this sulfate type, which does not achieve complete weight loss at temperatures below $900^{\circ} \mathrm{C}$. In fact, at temperatures below $900^{\circ} \mathrm{C}$, celestine shows only slight weight loss without reaching complete dissociation. Weight loss for celestine due to loss of $\mathrm{SO}_{3}\left(\mathrm{SO}_{2}+\mathrm{O}\right)$ and obviously reduction of celestine to the $\mathrm{SrO}$ compound occurs in the range of 950-1100 ${ }^{\circ} \mathrm{C}$. Complete weight loss due to $\mathrm{SO}_{3}$ loss occurs at temperatures of $1200^{\circ} \mathrm{C}$. The curves of the thermal behavior of the celestine sample analyzed in the paper are shown in Figure 5.

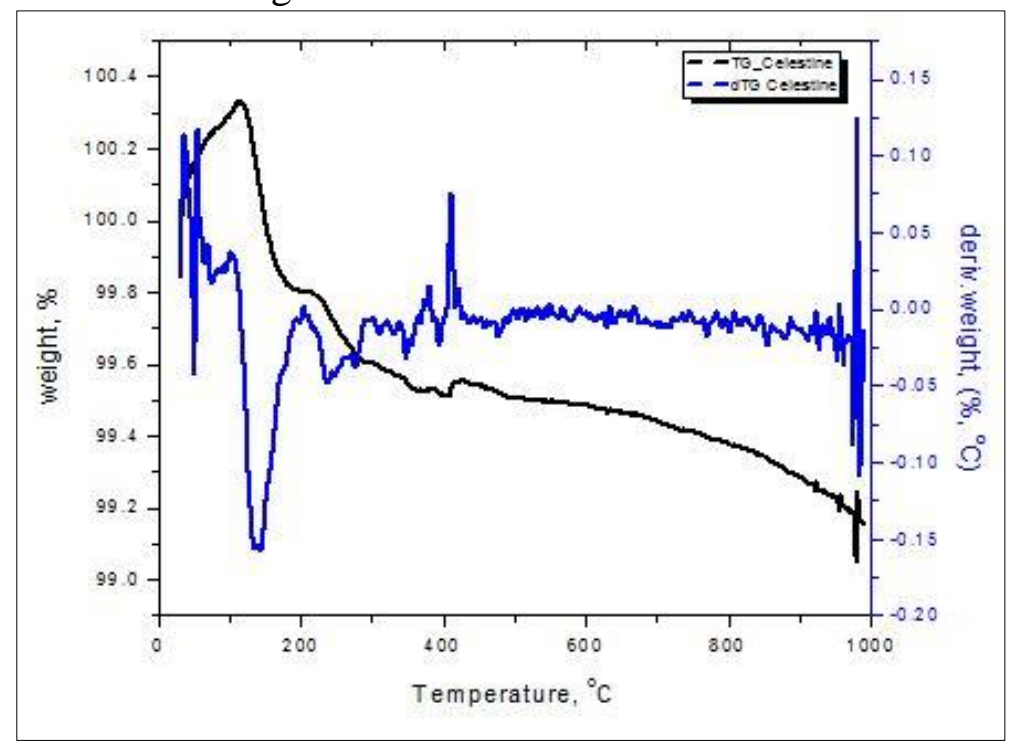

Figure 5. Thermal behavior of the celestine

\subsection{X-rays diffraction}

In the first steps of the XRD qualitative analysis using Basic (EVA) software the diffraction spectrum is prepared by removing the background and $\mathrm{K} \alpha 2$ radiation. In the following step by running the Search/Match option and PDF-ICDD 2-2008 database one or more crystalline phases/minerals are identified. The celestine phase was identified via sheet number 00-005-0593 as is shown in Figure 6.

Crystal structure refinement of the celestine sample was carried out using Topas 4.1 software. The peaks shape is Lorentzian and as peak profile function was used the pseudo-Voigt function. The graphical chart of the final refinement of the celestine structure is shown in Figure 7. 


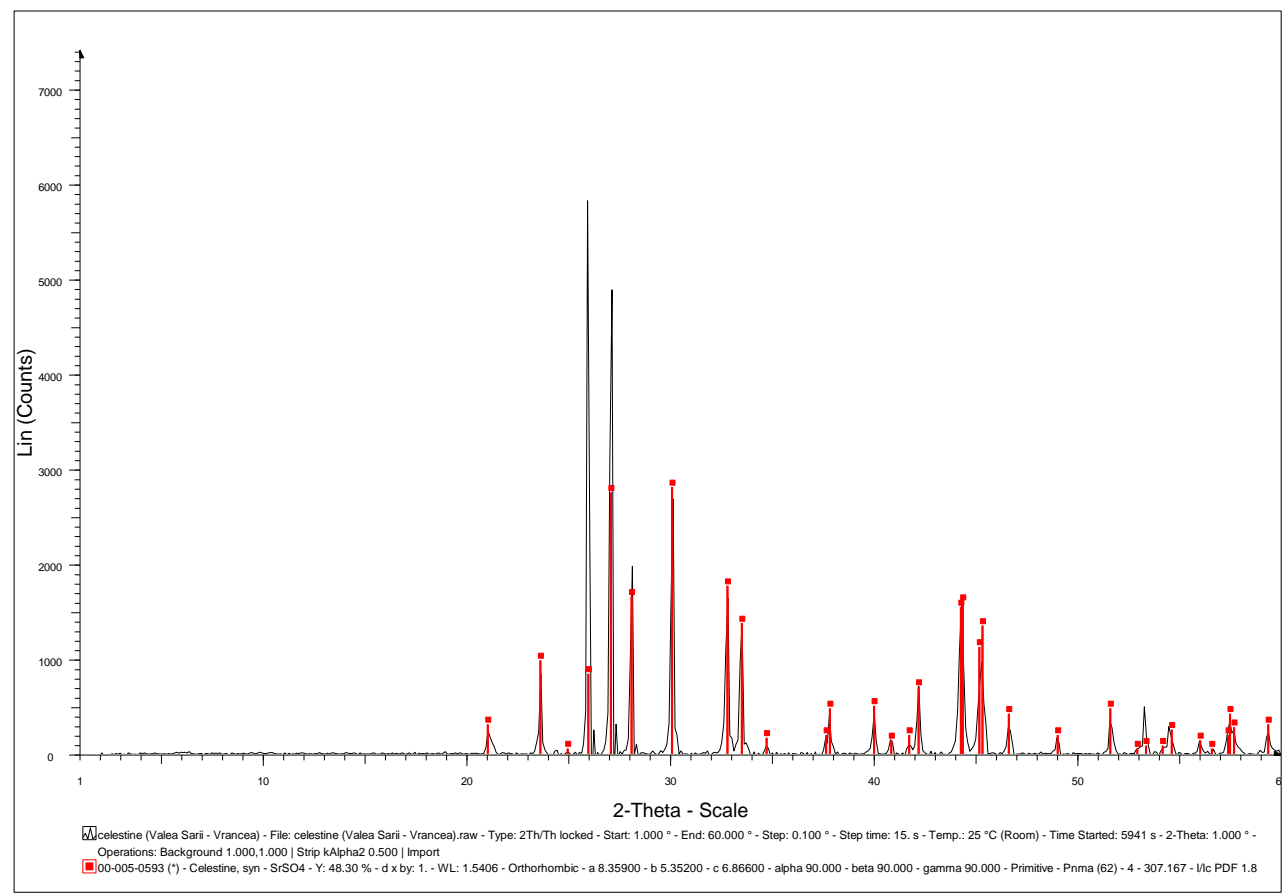

Figure 6. XRD qualitative chart of the celestine

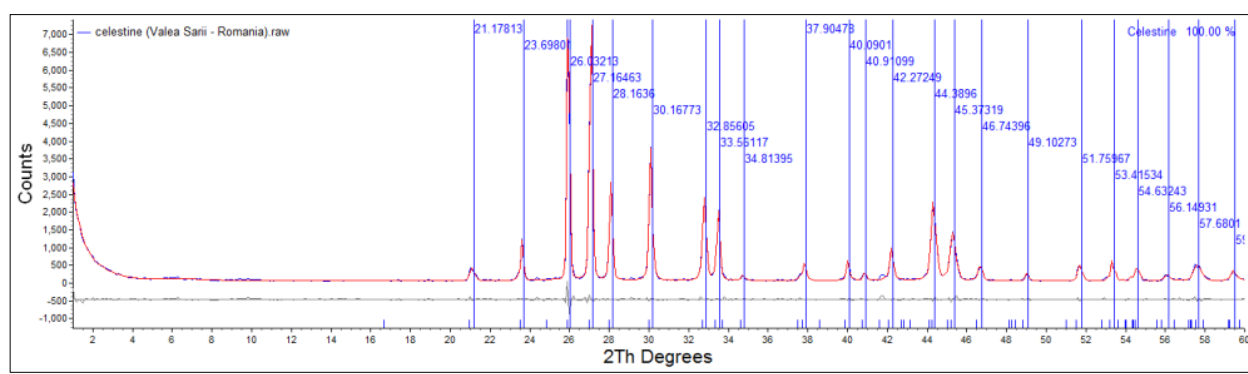

Figure 7. Final refinement of the celestine structure

Crystal structure refinement of the celestine led to the followings unit cell parameters: $a=8.39769$ $\AA, b=5.38415 \AA, c=6.88167 \AA, Z=4$ (space group Pnma). The quality of the structure refinement is characterized by the figures of merit, GOF and DW respectively, both indicating a good refinement. Other parameters that represent the quality of the Rietveld refinement are presented in Table 2.

Celestine is an $\mathrm{AB}$-type crystal structure composed of $\left(\mathrm{SO}_{4}\right)$ tetrahedral group bonded by strontium twelve-coordinated atoms. Besides the tetrahedral groups $\left(\mathrm{SO}_{4}\right)$, the $(\mathrm{Sr}-\mathrm{O} 12)$ polyhedra are also formed, in such a way that the $\left(\mathrm{SO}_{4}\right)$ and $(\mathrm{Sr}-\mathrm{O} 12)$ polyhedra share edges. The refinement shows the bond lengths strontium-oxygen $(\mathrm{Sr}-\mathrm{O})$ in the (Sr-O12) polyhedra are in the range 2.52-3.26 $\AA$. Also, in the $\left(\mathrm{SO}_{4}\right)$ tetrahedra the bond lengths sulfur-oxygen $(\mathrm{S}-\mathrm{O})$ are in the range 1.45-1.49 $\AA$, and the bond lengths oxygen-oxygen (O-O) are in the range 2.40-2.47 $\AA$. The bond lengths calculated are in good agreement with previous papers [7-13]. Atomic positional parameters and isotropic thermal factors for the celestine structure calculated in the refinement are presented in table 3 . The atoms position and the bonds between atoms in the refined celestine structure are shown in Figure 8.

Table 2. Rietveld refinement quality parameters of the celestine structure

\begin{tabular}{|c|c|c|}
\hline Parameter & Value & 2-sigma \\
\hline$a(\AA)$ & 8.39769 & 0.03164 \\
\hline$b(\AA)$ & 5.38415 & 0.04675 \\
\hline$c(\AA)$ & 6.88167 & 0.02547 \\
\hline$Z$ & 4 & - \\
\hline
\end{tabular}




\begin{tabular}{|c|c|c|}
\hline Cry size $\mathrm{L}(\mathrm{nm})$ & 596.45 & 0.02456 \\
\hline Cry density $\left(\mathrm{g} / \mathrm{cm}^{\wedge} 3\right)$ & 4.002 & 0.04826 \\
\hline Cell Volume $\left(\AA^{\wedge} \wedge\right)$ & 311.151 & 0.05659 \\
\hline R Bragg & 92.123 & - \\
\hline $\operatorname{Rwp}(\%)$ & 9.41 & - \\
\hline $\operatorname{Rexp}(\%)$ & 7.76 & - \\
\hline Rp $(\%)$ & 8.62 & - \\
\hline GOF & 1.21 & - \\
\hline DW & 2.09 & - \\
\hline \multicolumn{2}{|l|}{} \\
\hline
\end{tabular}

Table 3. Atomic positional parameters of the celestine structure

\begin{tabular}{|l|l|l|l|l|l|l|l|}
\hline Atom & $\mathbf{N p}$ & $\mathbf{x}$ & $\mathbf{y}$ & $\mathbf{z}$ & $\mathbf{O c c}$ & Beq & 2-sigma \\
\hline $\mathrm{Sr}$ & 4 & 0.16443 & 0.25000 & 0.17914 & 0.971 & 0.3373 & 0.0268 \\
\hline $\mathrm{Ba}$ & 4 & 0.16443 & 0.25000 & 0.17914 & 0.029 & -0.9494 & 0.0336 \\
\hline $\mathrm{S}$ & 4 & 0.46910 & 0.75000 & 0.24099 & 1 & 0.2773 & 0.0512 \\
\hline $\mathrm{O} 1$ & 4 & 0.29167 & 0.75000 & 0.25503 & 1 & -1.8433 & 0.0437 \\
\hline $\mathrm{O} 2$ & 4 & 0.18234 & 0.75000 & 0.48712 & 1 & -0.8046 & 0.0445 \\
\hline $\mathrm{O} 3$ & 8 & 0.39784 & 0.97469 & 0.28107 & 1 & -1.8564 & 0.0616 \\
\hline
\end{tabular}

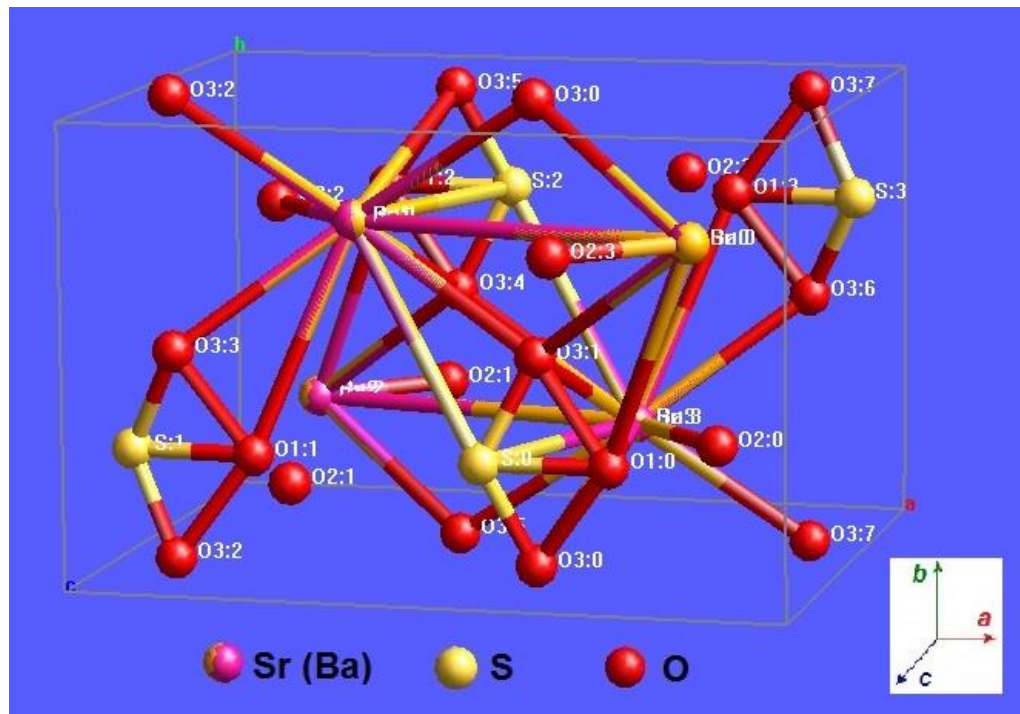

Figure 8. The position of atoms and the bonds in the refined celestine structure

\section{Conclusions}

The crystal structure of the celestine sample from Valea Sarii (Vrancea region, Romania) has been refined by the Rietveld method in the space group Pnma. The unit cell parameters of the celestine crystals resulted in the refinement were: $a=8.39769 \AA, b=5.38415 \AA, c=6.88167 \AA, Z=4$. The chemical composition of the celestine crystals was determined by SEM/EDX analysis. The optical characteristics of the celestine sample were studied by optical microscopy. The thermal behavior of the sample studied was revealed by thermal analysis. A new set of the unit cell parameters and atomic fractional coordinates of the celestine crystal structure were determined. Also were determined the bond lengths in the $\mathrm{Sr}-\mathrm{O} 12$ and $\mathrm{SO}_{4}$ polyhedra. Based on the Rietveld structure refinement and EDX analysis the chemical formula of the celestine crystals studied in the paper is $\left(\mathrm{Sr}_{0.97} \mathrm{Ba}_{0.03}\right) \mathrm{SO}_{4}$.

\section{References}

1.ABDEL HALIM, K.S., IBRAHIM, S.S., EL-BARAWY, K.A., Isothermal reduction behaviour of celestite concentrate by solid carbon, Mineral Processing and Extractive Metallurgy, 118 (4), 2009, 222-226. 
2.GEORGESCU, O., BRANOIU G., Mineralogie descriptiva, Editura Universitatii Petrol-Gaze din Ploiesti, 2005, 181-182.

3.SIRBU, P.D., TUDOR, R., VERINGA, V., CIUNTU, B.M., RADU, V., CIUBARA, B., BADULESCU, O.V., Strontium Ranelate in the Healing of Fractures Complicated with Delayed Union. It is Really Effective?, Rev. Chim., 68(8), 2017, 1825-1828.

4.CEHLAROV, A., Studii mineralogice si litologice ale depozitelor neogene dintre valea Milcovului si valea Putnei, cu privire speciala asupra acumularii de celestina de pe pârâul Valea Sarii, judetul Vrancea. Teza de doctorat, Univ. Bucuresti, 1998.

5.DOVE, P.A., CZANK, C.A., Crystal chemical controls on the dissolution kinetics of the isostructural sulphates: celestite, anglesite, and barite, Geochimica et Cosmochimica Acta, 59 (10), 1995, 19071915.

6.BRANOIU, G., 2012, The Rietveld structure refinement of the barite crystals from Somova (Romania) using X-ray powder diffraction data, Conference Proceedings of the 12th International Multidisciplinary Scientific Geoconference SGEM 2012, vol. 1, p. 357-362.

7.JACOBSEN, S.D., SMYTH, J.R., SWOPE, R.J., DOWNS, R.T., Rigid-body character of the SO4 groups in celestine, anglesite and barite, Canadian Mineralogist, 36, 1998, 1053-1060.

8.ANTAO, S.M., Structural trends for celestite $\left(\mathrm{SrSO}_{4}\right)$, anglesite $\left(\mathrm{PbSO}_{4}\right)$, and barite $\left(\mathrm{BaSO}_{4}\right)$ : confirmation of expected variations within the $\mathrm{SO}_{4}$ groups, American Mineralogist, 97, 2012, 661-665. 9.HAWTHORNE, F.C., FERGUSON, R.B., Anhydrous sulphates. I. Refinement of the crystal structure of celestite with an appendix on the structure of thenardite, Canadian Mineralogist, 13, 1975, 181-187.

10.GARSKE, D., PEACOR, D.R., Refinement of the structure of celestite $\mathrm{SrSO}_{4}$, Zeitschrift für Kristallographie, 121, 1965, 204-210

11.BRIGATTI, M.F., GALLI, E., MEDICI, L., Ba-rich celestine: new data and crystal structure refinement, Mineralogical Magazine, 61, 1997, 447-451.

12.JAMES, R.W., WOOD, W.A., The crystal structure of barytes, celestine and anglesite. Proceedings of the Royal Society of London, 109, 1925, 598-620.

13.MIYAKE, M., MINATO, I., MORIKAWA, H., IWAI, S.I., Crystal structures and sulphate force constants of barite, celestite and anglesite, American Mineralogist, 63, 1978, 506-510.

14.SITEPU, H., ZAIDI, S.R., Structural refinement of BaxSr1-xSO4 using X-ray powder diffraction data, JCPDS-International Centre for Diffraction Data, 2011, 1-8.

Manuscript received: 4.05 .2020 